\title{
Civil society mobilization in coping with the effects of COVID-19 in Brazil
}

\section{Carolina Andion 1}

1 Universidade do Estado de Santa Catarina / Graduate Program in Administration, Florianópolis / SC - Brazil

This text discusses the role of civil society in public action to face the consequences of the COVID-19 pandemic in Brazil. Based on a pragmatic approach, the study examines the collective actions promoted by civil society actors in Brazil, highlighting the characteristics, scope, and limits in the governance of this crisis. The study uses documental analysis to observe the recent mobilization of civil society in the country and field research to explore the reality of the city of Florianópolis. The results offer an overview of the performance of "invisible networks" of civil society actors, pointing out the challenges and outcomes of their actions. The findings suggest the need for further studies exploring the role, perspectives, and dilemmas of civil society in the production of "experimentalist governance" in response to the numerous challenges posed by the pandemic at the local level.

Keywords: COVID-19; civil society; public action; governance; democratic experimentalism.

\section{Atuação da sociedade civil no enfrentamento dos efeitos da COVID-19 no Brasil}

\section{"O essencial é invisível aos olhos."} Antoine de Saint-Exupéry

\begin{abstract}
Este texto discute a atuação da sociedade civil na ação pública para o enfrentamento das consequências da pandemia da COVID-19 no Brasil. Partindo de uma lente pragmatista de análise, examinamos as ações coletivas da sociedade civil no combate aos efeitos da COVID-19, ressaltando suas características, seus alcances e seus limites na governança dessa crise. Para tanto, em primeiro lugar, por meio de um levantamento documental, analisamos a mobilização recente da sociedade civil e, depois, examinamos a realidade da cidade de Florianópolis, a qual acompanhamos mais de perto, mediante pesquisa de campo. Os resultados permitem construir um panorama da atuação dessas "redes invisíveis" e lançar pistas sobre as consequências e os desafios dessa atuação. As conclusões chamam a atenção para a necessidade de explorar mais a fundo o papel, as possibilidades e os dilemas da sociedade civil na produção de uma "governança experimentalista" em resposta aos inúmeros desafios impostos pela crise causada por essa pandemia no âmbito local.
\end{abstract}

Palavras-chave: COVID-19; sociedade civil; ação pública; governança; experimentação democrática.

\section{Acción de la sociedad civil para enfrentar los efectos de la COVID-19 en Brasil}

Este texto analiza el papel de la sociedad civil en la acción pública para enfrentar las consecuencias de la pandemia de COVID-19 en Brasil. Partiendo de una perspectiva de análisis pragmática, examinamos las acciones colectivas promovidas por los actores de la sociedad civil en Brasil en la lucha contra la COVID-19, destacando sus características, su alcance y sus límites en la gobernanza de esta crisis. Para ello, primero, a través de análisis documental, investigamos la reciente movilización de la sociedad civil en el país y, en un segundo momento, examinamos la realidad de la ciudad de Florianópolis, que seguimos más de cerca, a través de investigación de campo. Los resultados permiten construir una visión general de la acción de estas "redes invisibles" y proporcionar pistas sobre sus consecuencias y desafíos. Las conclusiones llaman la atención sobre la necesidad de explorar más a fondo el papel, las perspectivas y dilemas de la sociedad civil en la producción de una "gobernanza experimentalista" en respuesta a los numerosos desafíos planteados por la crisis causada por esta pandemia a nivel local.

Palabras clave: COVID-19; sociedad civil; acción pública; gobernanza; experimentalismo democrático. 


\section{INTRODUCTION}

An analysis of the responses of Brazilian civil society to the consequences of the COVID-19 can help us better understand the characteristics of these actions in terms of answers to public problems, as well as their contribution and their limits within the context of public administration. This is because the unprecedented situation imposed by the pandemic in various countries is an important situation of uncertainty which opens up possibilities to rethink and reinvent the classic forms of governing, practicing public governance and the actions of civil society itself.

The COVID-19 pandemic can be viewed as a "proof situation,"1 a bifurcation moment which opens up possibilities to question the status quo and reinvent established institutions and practices. This "problematic situation" also imposes new forms of coordination and governance to respond to countless public problems in the areas of health, economics, social protection, and politics, among other areas. In a situation like this, there is no way to define objectives and metrics a priori, which need to be constantly revised, based on various forms of expertise and practices in the course of promoting learning, adaptation and effective solutions for the diverse and complex challenges imposed on public administration which demand intersectoral and interdisciplinary responses.

Even though the urgent situation imposed by the pandemic is critical, it can generate experiments and new forms of relationship between civil society, State and public administration. Comprehending these processes is a pressing need in the current Brazilian situation, given that the country is the epicenter of the pandemic - with an exponential increase in coronavirus cases and deaths which have spread to the interior of the country - which has been internationally recognized as one of the worst examples of governance during this crisis. This is due to various aspects, ${ }^{2}$ such as: (1) the gradual collapse of the health systems in various states; (2) a lack of coordination and communication and the recurring conflicts between the various powers and levels of government; (3) a profound inequality in terms of territory, income, life conditions and access to public health services and social protection; (4) formalism, a lack of coverage and a lack of funds budgeted for public health and social policies; (5) escalating authoritarianism, lack of transparency and political polarization, amplified by the postures of the President and the high level of his administration in facing the pandemic.

Given this scenario, several questions can be posed: how has civil society act and what have been the characteristics of these collective actions in the combat against COVID-19 in Brazil? What are the extent and limits of its actions? What are its contributions to the governance of the crisis? To what extent do these actions promote processes of "democratic experimentation?" These are questions that this study will address in an exploratory manner in the following sections.

To accomplish this, we will begin with the debate about the relationship between the State and civil society, discussing the importance of its interaction in public actions. The predominant perspectives in

\footnotetext{
${ }^{1}$ As Chateauraynaud (2011, p. 16) points out, the concept of proof is central to pragmatism and pragmatic sociology. A proof situation constitutes a moment of uncertainty and indetermination in the life and path of the actors, when possibilities of a change of the states of worth and its relationships are revealed through the flow of action. In these moments, people need to test their abilities to act, design, qualify, judge or justify something or someone. It is a quintessential moment of uncertainty and indetermination, but it is also an opportunity to reach new agreements between beings (people or things).

${ }^{2}$ Various articles, which have recently been published in the media in Brazil, have been written by colleagues of public administration field discussing these problems. To access one of the most recent of these, see Abrucio and Teixeira (2020).
} 
this debate are considered to expose the differences between the postulated forms of governance and the "experimentalist governance" adopted in this study. Next, we will construct a general panorama of the collective actions of civil society in the fight against the pandemic in this country, examining its main characteristics and effects. This will be realized by analyzing secondary data in reports and digital platforms produced by reference institutions which gather information about its conduct. ${ }^{3}$

In the third section, using a descriptive and interpretive case study (Godoy, 2006), we will examine more closely the mobilization of civil society in Florianopolis in the face of the effects of COVID-19 in the city. This study was performed by exploring primary and secondary data through the cartography of the public arena. ${ }^{4}$ This made it possible to identify 44 civil society initiatives that faced the effects of the pandemic in Florianopolis, and to observe more closely some of these experiences, accompanying the public discussion about this subject, with the participation of the author in debates about this issue in various scenes in the city. ${ }^{5}$ To conclude, the final considerations will be presented regarding the performance of civil society and the factors that stimulate or hinder the exercise of an "experimentalist governance" in response to the crisis imposed by the pandemic, based on cross-references of this study's findings.

\section{DISCUSSING THE ROLE OF CIVIL SOCIETY IN PUBLIC ACTIONS}

Traditionally, a State-centered conception has dominated the debate in public administration theory and practice, in which the government is viewed as the principal or exclusive player in the act of governing. Over the past few decades, however, it appears that a consensus has been reached in terms of the need to rethink this conception, given the challenges imposed by the management of more and more challenging and complex public problems. With this, a multicentric or multi-actor approach has emerged which considers that the scope of governing extends far beyond the government. The idea of governance compels us to look at the various forms of interaction and joint coordination between civil society and the government, emphasizing the multipolarity of the instituted powers, their fluidity and decentralization (Gaudin, 2002; Salamon, 2011; Levi-Faur, 2012). Even though there is a consensus in regard to this (re)interpretation, governance has become an umbrella term, which provides space for distinct readings and perspectives ${ }^{6}$ about what should be this interaction between the State and civil society and what the role of this is in public actions.

\footnotetext{
${ }^{3}$ The utilized references are cited during the analysis in the third section.

${ }^{4}$ The cartography of the public arena was realized through the Social Innovation Observatory of Florianopolis, a collaborative online platform, constructed by the research which this study take part (www.observafloripa.com.br) and implemented in 2017. The inquiry for this study, from April to June 2020, start from other mappings already realized in the city, which were complemented by the researcher. For more detail on the theoretical-analytical and methodological focus applied in this study, see Andion, Alperstedt, and Graeff, $(2019,2020)$.

${ }^{5}$ On April 3, the author shared an online conversation with the Secretary of Social Assistance about the actions of the City Hall in relation to the pandemic. On April 15, the author participated remotely in a public debate with the City Council and the Secretary of Social Assistance about the government's actions in the face of the COVID-19 pandemic in the city. On May 27, she took part and moderated a seminar about the actions of civil society organizations (CSOs) in the combat against COVID-19, and, on June 2, she joined the Assembly of the Forum of Public Policy of Florianopolis (FPPF), a space for the articulation of collectives, social movements, civil society users and organizations which participate in public policy councils.

${ }^{6}$ Due to a question of focus, the broad debate about public governance will not be considered here, and instead we will focus on the main theoretical streams which discuss the collective actions of civil society in the public sphere (Cefaï, 2007) and explore its interface with governance. For a deeper discussion of governance and its various perspectives, see Gaudin (2002) and Levi-Faur (2012).
} 
A first perspective, very influential in Brazil, is anchored in the rationalist paradigm and is inspired by the Resource Mobilization Theory (McCarthy \& Zald, 1977). It is related to the concept of the third sector and/or the notion of third-party government (Salamon, 2011). Within the movement of "reinventing government", in light of the reforms inspired by New Public Management, this perspective interprets civil society as a complementary sphere dependent on governmental action. The notion of "interdependence" (Salamon, 1995) is offered as an alternative to increase the efficiency of the State and diminish its costs. Governance here occurs through the control of the principal (the government) in relation to the agent, which consists of civil society organizations (CSOs), which assume the role of providing public services and/or goods. Many studies, however, have exposed the limits of this perspective, which often translates into the practice of the cooptation of civil society, leading to a loss of autonomy in its actions making it more functional than transformative (Meyer \& Maier, 2015).

A second conception, which is also very influential in Latin America, is grounded in the New Social Movements paradigm and interprets civil society actors as change agents in a broader social and political context. The studies based in this this vision seek to demonstrate the capacity of political mobilization of these groups, contributing to create new collective identities and rights, focusing on conflict as a key notion (Cohen \& Arato, 1994). Here, the influence of governance is through pressure, social control, and political and social fights waged by social movements in various fields of rights.

These two interpretations of the interaction involving civil society and the State, which are to some extent opposite, dominated the debate until the 1980s and were incorporated in the frameworks of analysis which suppose civil society some times as a partner and others as an adversary of the government (Young, 2000).

A third and more recent standpoint, dialogues with the theory of Political Mobilization (Tarrow, 2009) and promotes an articulation between these first two schools of thought. Studies along these lines broaden the debate about the importance of the participation of civil society, by considering multiple forms of political representation, social control and legitimacy within the context of democracies (Almeida, 2014). This debate about participative instances (PIs) has grown in Brazil and Latin America in recent years. It treats the extent and limits of participation and deliberative processes, as well as the involvement of civil society in governance systems in view of the crises faced by representative democracies.

Without ignoring the importance of each of these conceptions, it can be stated that all of them are based on the fundamental idea that civil society and the State are separate entities/enclaves. The conceptions of politics, governance and democracy adopted are formal and institutional. Government, governance and their dimensions are promoted apart of civil society - which has the role of repairing the fissures of the system from a managerial perspective, or the functions of opposing/demanding/ pressuring or even participating in the State and thus, controlling it.

More recently, some studies have emphasized the importance of looking at the relationships between the State and civil society, further discussing the naturalization of this foundational duality (Ansel, 2011; Brandsen, Trommel, \& Verchuere, 2017; Frega, 2019; Lavalle \& Szwako, 2015; Sabel, 2011; Sabel \& Zeitlin, 2012). These studies offer clues to reinterpret civil society as an intrinsic and constitutive space of the democratic State and the public actions promoted by it. In this way, public actions are not limited to governmental actions that the State determines/ascribes to/controls; it has 
relative autonomy, which is promoted in loco and in the intersection between what is instituted and social autonomy through societal-state associations, interfaces and responses co-constructed for public problems.

Dialoguing with the pragmatist point of view and with the precursor work of John Dewey (1927), these studies denaturalize the classic notion of the State, relating the dimensions of representation and legitimacy, typical of the idea of government, and the dimension of the resolution of public problems (governance). As Ansell (2011) discusses, this approach implies broadening the interpretation of how public administration, its institutions and democracy itself function. This means to consider the codetermination of the State and civil society, focusing on the dynamics and logics that compose these societal-state interactions in a dynamic and reciprocal manner (Lavalle \& Szwako, 2015).

As a result, this interconnection between civil society and the State becomes central of an experimentalist style of governance (Sabel \& Zeitlin, 2012, p. 3), which is necessary in a world where the complexity of public problems requires constant readaptation. According to the authors, experimentalist governance refers to a "recursive process of provisional goal-setting and its constant redefinition, based on collaborative learning." This form of governance is put forward as a direct deliberative polyarchy. ${ }^{7}$ It is deliberative because it is open to argument, to inquiry and review of established concepts and practices. It is a polyarchy because, in the absence of a final and central decider, the various players of the governance systems have to learn and define their goals to face problems based on their relationships with others, in a collaborative manner.

While they face, learn from and act to respond to public problems, the collectives of civil society are constituted as "publics" (Dewey, 1927) which perform the "public arenas". The latter are defined by Cefaï (2012) at the same time as spaces of conflict and agreements, in which public actions are performed. Therefore, what is public is no longer a monopoly of the State and a democratic construction becomes something to be investigated, followed and viewed in light of public facts while these are being generated. Observing public arenas, we can better understand how actors face each other and commit themselves to a collective effort to define and control "problematic situations" as well as their effects.

To discuss the possibilities of this process of the reinvention of democracies given the current scenario, Frega (2019) offers important clues for this debate. The author revitalizes the discussion about the crisis in liberal democracies, seeking to demonstrate that this crisis is not just procedural or due to the draining of its participative substance. According to him, to construct new alternative routes to overcome this crisis, in theory and practice, it is important to rethink and reconstruct democracy beyond its formal conception, viewed as a combination of institutions which translate popular concerns into policy. This means considering the opportunities created by social interactions which constitute democracies as sources of creative actions, social innovation and institutional transformation.

Frega (2019) explores the potential of "democratic experimentalism" understood as an opportunity to transform what is instituted, which is essential to reinventing democracy. For him, democratic experimentalism provides theoretical and analytical insights to comprehend how democracy is related to social innovation. In addition to identifying the extent and limits of participative processes, it means to recognize the way in which the design of institutions occurs to face undesirable consequences of the life in common. The word "experimentation" refers to seeking more innovative solutions,

${ }^{7}$ For broader discussion of this concept, see Cohen and Sabel (1997). 
inquiring and testing in order to diminish the errors in responses to problematic situations which are contextualized. The word "democratic" is related to the processes of mutual collaboration and learning, valuing various forms of knowledge and expertise, especially of the affected publics. This process of collective and evolutionary learning, based on public inquiry, is considered by the authors to be an important element in the revitalization of public actions in current democracies.

In the same direction, Brandsen, Trommel, and Verchuere (2017) discuss whether these processes can make the reinvention of civil society and its form of acting in the public sphere possible, transforming the dichotomy between adversarial and collaborative relations with the State.

According to the authors, between the institutional logic of the State and the new emerging social dynamic in the local levels "collaborations develop between actors who have one foot in the 'old world' (professionals, managers, civil society organizations, local politicians, interest organizations, etc.) and the other in improvised social ground [...] The overarching value that binds these actors together might be characterized as a problem-driven search for 'public craftsmanship"' (Brandsen, Trommel, \& Verchuere, 2017, p. 687).

Given this preliminary theoretical discussion and the turbulent and undetermined scenario imposed by the COVID-19 pandemic in Brazil - with public problems that are more and more urgent and complex which may endure beyond this crises - we are seeking to understand the agency of civil society in this scenario, its characteristics and influence in public actions, from a perspective of democratic experimentation. We will now begin this analysis.

\section{THE MOBILIZATION OF CIVIL SOCIETY TO FACE THE COVID-19 PANDEMIC IN BRAZIL}

The mobilization of civil society to face the pandemic in Brazil has occurred since its outset and has been relevant as demonstrated by the data collected in the sources consulted by this study. One of the most complete of these reports refers to a mapping of initiatives combatting COVID- $19^{8}$ realized in a collaborative manner by the organization PonteAPonte which began in March. This mapping shows that two months after the country's first registered case of the disease, there were already hundreds of civil society initiatives to combat the undesirable effects of the pandemic involving private social investment (PSI) actors, CSOs, social movements, community groups, and initiatives promoted by social impact businesses.

By the end of April, the mapping already included 450 registered actions. The data collected was systematized in a report ${ }^{9}$ and confirmed by the analysis of other mappings realized by representative institutions in the field, such as the Group of Foundations and Enterprises (GIFE) ${ }^{10}$ the Brazilian Association of NGOs (ABONG) $)^{11}$, the Marielle Franco Institute, and Slum Agenda (Favela em Pauta) ${ }^{12}$,

\footnotetext{
${ }^{8}$ Collaborative mapping. Retrieved from https://docs.google.com/spreadsheets/d/1spIFsibSNv42B2eBBpZPH5L9qYhSiS 48SoSTG8sWHmE/edit\#gid=892611875

${ }^{9}$ The report Os primeiros 60 dias de COVID-19 no Brasil em 60 fatos, reflexões e tendências em filantropia, investimento social e no campo de impacto social. Retrieved from https://drive.google.com/file/d/14eHc2LhhoGbAaZaf46Aa5fe3iGbeQUzl/view

${ }^{10}$ The COVID-19 Emergency platform, developed by GIFE, focuses on PSIs, but also includes community or public funds and campaigns, as well as guides and tools. Retrieved from https://emergenciacovid19.gife.org.br/

${ }^{11}$ The ABONG platform called \#RedeSolidaria is focused on promoting engagement, donations and civil society actions. Retrieved from https://www.engajar.redesolidaria.org.br/

${ }^{12}$ The Coronavirus Map of the Periphery, an initiative of the Marielle Franco Institute and Slum Agenda (Favela em Pauta), constitute a mapping to give visibility to the fight against COVID-19 in the slums and peripheries of cities in Brazil. This can be retrieved from https://www.institutomariellefranco.org/mapacoronanasperiferias
} 
which can be accessed by the Society Against the Coronavirus platform ${ }^{13}$, which includes roughly 160 social movements, organizations and collectives of Brazilian civil society. The analysis of this data allows us to make some considerations and to build a panorama about the collective actions of Brazilian civil society in this scenario.

In terms of forms of acting in their majority, the promoted collective actions refer to fundraising campaigns or in natura donations to social assistance - with a focus on the distribution of food, hygiene and cleaning items - and health, with the purchase of protective and hospital equipment. An analysis of these campaigns makes it possible to observe a myriad of small endeavors, many led by actors which are already protagonists, above all business philanthropy or CSOs and collectives which support specific peripheral communities and/or groups. Even though they are fewer in number, there are also campaigns realized by the articulation of different actors and sectors - for example, União Rio ${ }^{14}$ and União São Paulo, ${ }^{15}$ group initiatives linked to PSIs - as well as collective actions in communities such as the Maré Mobilization Front ${ }^{16}$ and the COVID-19 campaign in the Slums ${ }^{17}$, realized by the movements themselves and by collectives in peripheries.

These articulations are also evident between intermediate actors which are field developers giving origin to new forms of promoting collective actions, such as the creation of online collaborative platforms, many of which served as sources for this study. These initiatives have produced relevant effects, such as the coproduction of new information and knowledge for this field, debates and exchanges of experiences through webinars and other online media, and the production of manifestos, among other initiatives. This points to other forms of collective actions and consequences beyond emergency responses.

In terms of the protagonists, the actions promoted by SPI actors stand out. These are led by institutes, foundations and companies, responsible for most of the investment, initiatives (57), and funds and campaigns (69) mapped by GIFE on the COVID-19 Emergency platform.

The analysis of this data also makes it possible to visualize the importance of mobilization in these peripheral communities, such as the actions promoted by the Unified Communications Center of the Slums (Central Única das Favelas - CUFA) ${ }^{18}$, not just in terms of fundraising, but also in the promotion of health, the prevention of this contagion, and the mobilization of volunteers, among other things. In an equal manner, the solidarity campaigns promoted by NGOs and social movements focused on specific groups, such as indigenous and quilombo residents, homeless population and others, stand out. On the \#Solidarity Network (\#Rede Solidária) platform, developed by ABONG, more than 40 initiatives like these have been mapped. These movements have played an important role in shedding light on the life conditions, demands and vulnerabilities of the groups and populations that are often invisible to public policies.

In terms of the investment in monetary resources, the total donated to combat COVID-19 as of the beginning of June 2020 - according to the donation monitor developed by the Brazilian Association

\footnotetext{
${ }^{13}$ Retrieved from https://www.sociedadecontraocorona.org/

${ }^{14}$ To find out more see https://www.movimentouniaorio.org/

${ }^{15}$ To find out more see https://www.uniaosp.org/

${ }^{16}$ The front was formed on March 19. The initial objective was to stimulate actions which would provide the residents of 16 communities in Maré with information. Currently, it is made up of roughly 140 thousand members and promotes various mobilization actions about the importance of self-protection, ensuring hygienic habits and respect for social distancing. To find out more see https://www.frentemare.com/

${ }^{17}$ To find out more see https://www.covid19nasfavelas.meurio.org.br/\#block-14403

${ }^{18}$ To find out more see https://www.facebook.com/cufabr/
} 
of Fundraisers (ABCDR) ${ }^{19}$ - was $\mathrm{R} \$ 5,545,031,943$. Of this total, $83 \%$ was donated by companies; $7 \%$ by campaigns and live events; $5 \%$ by individuals and families; and $2 \%$ by foundations, philanthropic institutes and churches. The progression of donations, expressed in Figure 1 below, demonstrates a continual increase in the amount donated and the number of donors, which indicates that the emergency situation of the pandemic has stimulated the culture and practice of donating in this country.

\section{FIGURE 1 MONITORING OF COVID-19 DONATIONS}

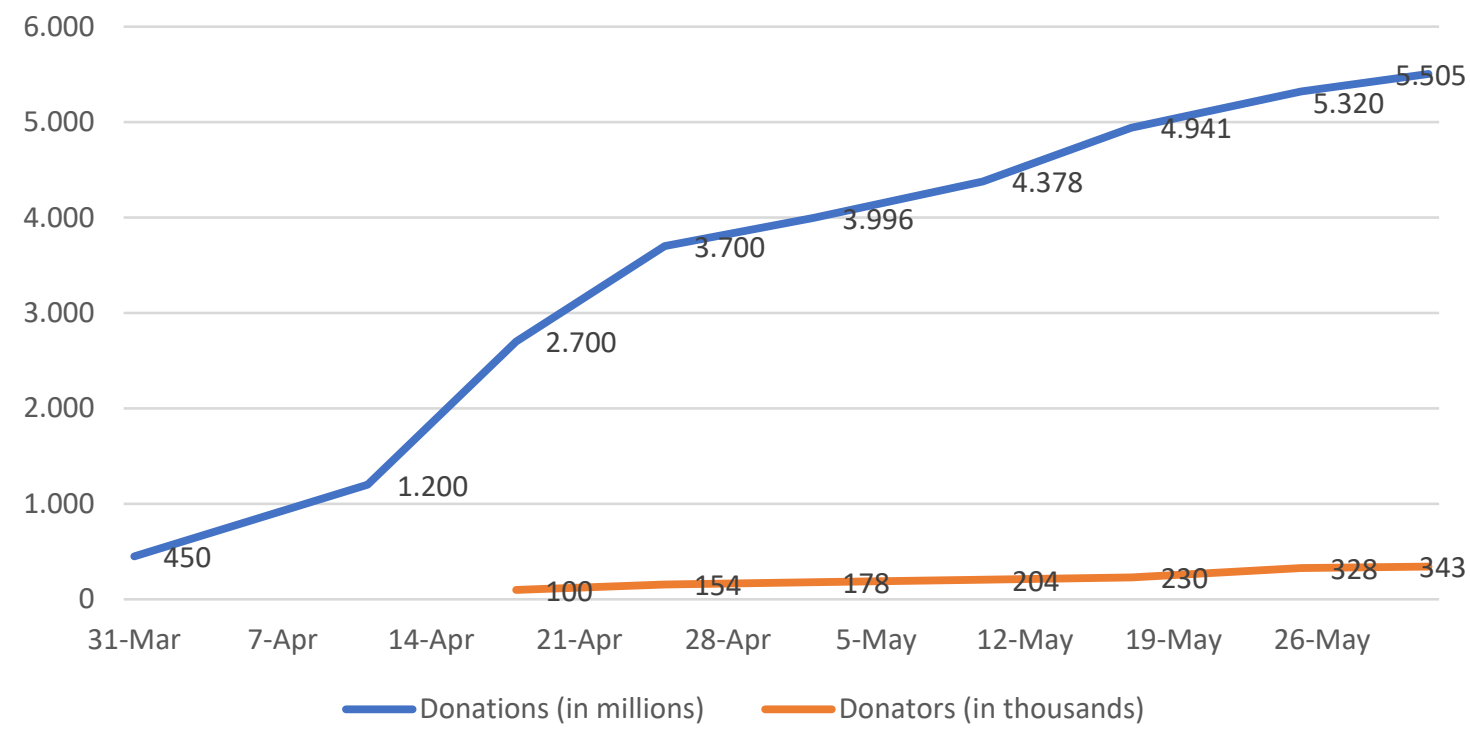

Source: Brazilian Association of Fundraisers (2020)

In terms of the geographic distribution of the actions, all of the mapping shows a greater concentration of actions by civil society in the Southeast region of the country, above all in the cities of Rio de Janeiro and São Paulo. Thus, this indicates the importance of radiating social investments to the more remote zones of Brazil, to more vulnerable municipalities that face the pandemic, avoiding the concentration of resources and actions.

The analyzed data is not exhaustive, but it signals the relevance of civil society's participation in the fight against COVID-19 in Brazil, whether it is in terms of the investment of financial resources or the mobilization of expertise and/or the collective construction of answers to confront the effects of the pandemic, especially in terms of the more vulnerable population. The results reveal that the most common actions have occurred in an urgent and decentralized manner, being more accentuated in the fields of social assistance and health, mainly in the Southeast region of the country, led by actors which are already protagonists.

This indicates that the pandemic situation takes advantage of preexisting regimes and logics of previous paths in the field which have already been signaled in previous studies (Dagnino, 2002; Landim

${ }^{19}$ Retrieved from https://www.monitordasdoacoes.org.br/ 
\& Scalon, 2000) and by national mappings such as those conducted by private foundations and nonprofit associations (Fasfil) and CSO maps. ${ }^{20}$ These analyses show that historically up until now the CSO field in Brazil has been marked by an assistentialist pattern, dominated by religious organizations which provide social assistance, education, health, sports and leisure services, in a complement to State.

Despite they are fewer in number, the results also make it possible to identify initiatives which go beyond urgent needs and indicate new regimes of governance, engagement and mobilization within the public sphere, involving or not monetary resources. The leading role of the peripheral communities themselves stand out. They create funds, establish channels to publicize public problems, denounce abuses and produce critiques and inquiries, which has led to interesting changes in the landscape and has had important effects in the governance of this crisis.

These collective actions to face the pandemic have created a space for a certain "reinvention of civil society" and for the emergence of social experimentations and innovations, even though they are not the rule. But to make a bridge with the previous theoretical discussion, to what extent does this movement go beyond individual experiences and can it generate democratic experimentation? What is its interface with governance and public policies? What lessons can be learned from this? Trying to respond to these issues, the findings about the national scale will be related to the reality of a city, the laboratory in which public actions occur. To do this, we will examine the situation in the public arena that faces COVID-19 pandemic in Florianopolis, which has been followed more closely by field research.

\section{A CLOSER ANALYSIS OF THE ACTIONS OF CIVIL SOCIETY: AN EXAMINATION OF FLORIANÓPOLIS}

As demonstrated on a national scale, the analysis of the public arena mobilized around the pandemic problems in Florianopolis shows that the performance of civil society has made a difference in the crisis's effects on the city. Its importance has increased given the delay in liberating emergency funds approved by Congress and the lack of governance and responses offered by municipal public policies, especially social assistance policy which addresses the needs of the most vulnerable population. ${ }^{21}$

Florianopolis, despite having the third highest Human Development Index rating in Brazil, has 67 zones of social interest in which 123,239 people live (24.6\% of its population) in a situation of extreme poverty, earning up to half minimum wage (Brazilian Institute of Geography and Statistics [IBGE], 2010). At the beginning of the pandemic, the city led the number of confirmed cases of COVID-19 in the state, and currently (at the end of July) it is the fifth city in the state of Santa Catarina and the first in Greater Florianopolis, with a total of 2,754 diagnosed coronavirus cases and 41 deaths.

The cartography of the public arena performed by this study has made it possible to identify 44 initiatives ${ }^{22}$ promoted by civil society actors to combat the COVID-19 pandemic. Most (38) are led by

\footnotetext{
${ }^{20}$ The 2010 Fasfil data (Abong et al., 2012) and the CSO map (Accessed at https://mapaosc.ipea.gov.br/) demonstrate that most of the Brazilian associations and foundations are concentrated in the Southeast, are religious and/or operate in the fields of education, health, or social assistance. Equally they reveal that over the past decade these organizations have been politicized and divide space with those which defend rights.

${ }^{21}$ Up until the beginning of April, the municipal government had promoted actions to support the most vulnerable families, with the implementation of a lunch card of R \$100 a month for 2,457 children in municipal schools and also of R $\$ 100$ a month for 1,226 autonomous professionals. In addition, 3 thousand basic meals were distributed through the Somar Network, a voluntary network headed by the mayor's wife. In addition to being insufficient to meet demand, the Reference Centers of Social Assistance (CRAS and CREAS) were closed, and service was then offered by telephone or online, which made it more difficult for families to get access to these benefits. ${ }^{22}$ The list of initiatives and their characteristics are available on this study's online platform. To access it, see http://www.observafloripa.
} 
actors which have already acted in the city's social innovation ecosystem (SIE). The network formed by the mapped, observed and accompanied initiatives ${ }^{23}$, as well as their support actors, is illustrated in Figure 2 below.

Of the total mapped, 90\% (40) are fundraising campaigns for the purchase and donation of basic meals and hygienic material, with most being for families already served by the CSOs (mostly associations). Eleven are promoted by social collectives or movements, seeking to serve specific groups such as the indigenous, quilombo, homeless, elderly and student populations which are vulnerable. Just nine are promoted by broader articulations, involving interactions between government and civil society, partnerships between universities and civil society, or the connection of more than one civil society organization/movement. Thus, the role of recognized intermediary organizations stands out, acting as articulators, such as the Vilson Groh Institute (IVG), showcased in Figure 2, and the Greater Florianopolis Community Institute (Icom).

\section{FIGURE 2 REPRESENTATION OF INITIATIVES NETWORK AND ITS SUPPORTERS IN THE FIGHT AGAINST COVID-19 IN FLORIANÓPOLIS}

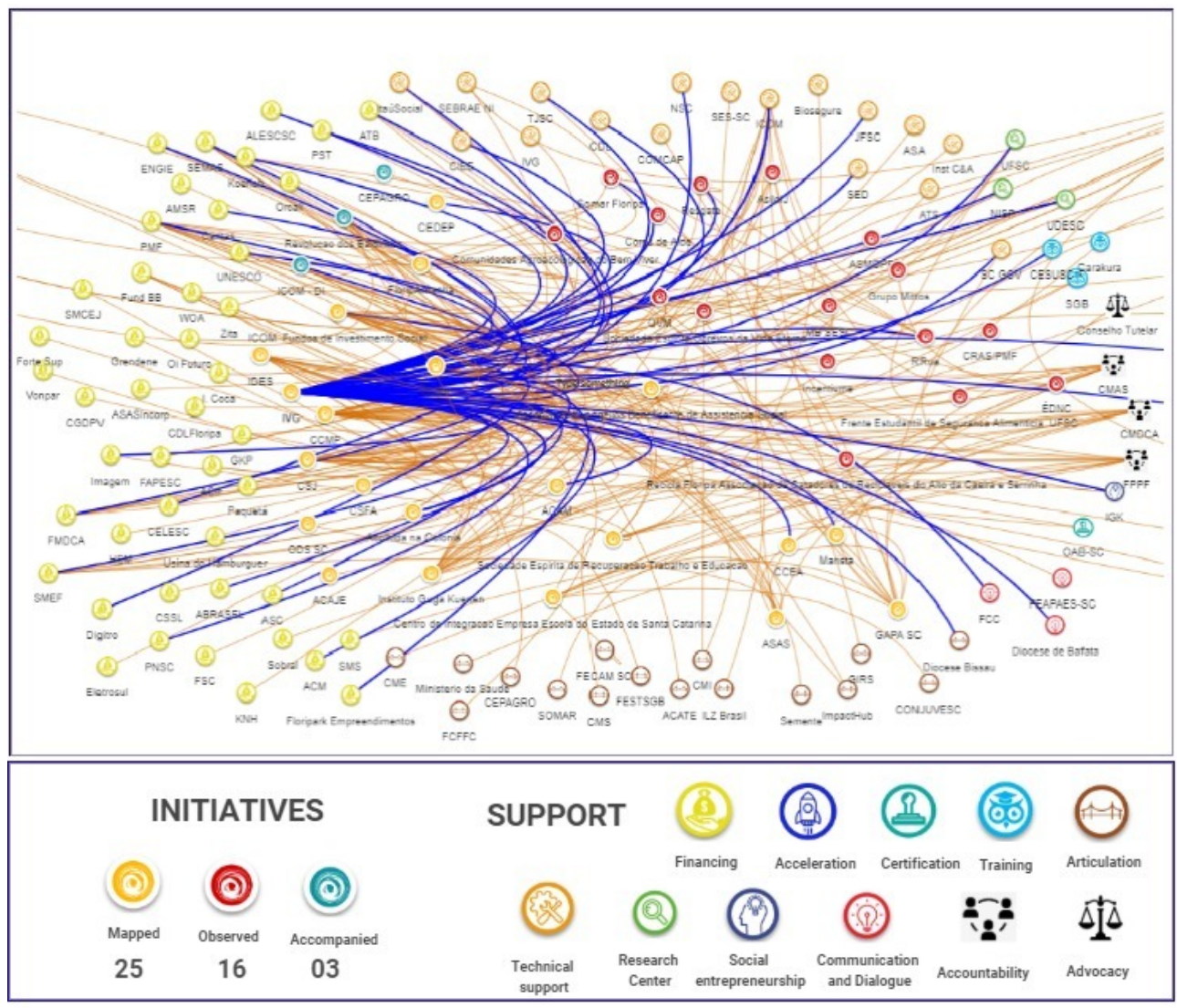

Source: Field research.

com.br/is-page//publicProblemsDetails?id=57

${ }^{23}$ The accompanied initiatives are those which are being researched systematically by the observatory team. Observed initiatives are those which have had all of their survey information complemented and validated by the team. Mapped initiatives are those identified by indication or self-registration on the platform. 
Looking closer at this public arena, we can observe that the initiatives follow the pattern of the national reality, explored above, promoting actions of social assistance for families and communities that they already helped before the pandemic. These actions have been of great relevance given the gap in governmental responses and the urgency of the situation, described above. But beyond these emergency actions, what is the potential of democratic experimentalism in this network? In relation to this question, it is important to explore some experiences accompanied by this study, in which greater articulation and results were observed as well as effects in terms of public actions.

The first experience has been with the COVID-19 Emergency Support Fund sponsored by Icom, which is an association that acts as a community foundation in the Greater Florianopolis region and was created in 2005 by a group of female leaders who were already active in PSIs and the city's civil society. At the beginning of social distancing, during the second week of March, Icom dedicated one of its existing funds to supporting families in social vulnerability through the donation of basic meals. At the end of March, the CSO received an investment of R \$ 500 thousand from the Itaú Social Foundation, which led to the creation of a consultative committee for the fund formed by experts and community leaders, resulting in the proposal of the creation of a community bank and social currency, a pioneering experience in the South region.

The bank has been implemented through a partnership between Icom and community CSOs which are co-realizers, and it functions through the creation of a social currency which are being used by participating families to buy food and hygienic products in local supermarkets and stores for three months. This pilot phase is being implemented in three communities: Serrinha, Chico Mendes and Monte Serrat. The fund has mobilized 294 social investors until June 2020, including individuals and companies who have donated a total of R \$666,272 and support 931 families and 21 CSOs with donations of basic meals. The bank, in turn, benefits up to 502 families, 3 CSOs and 16 local stores in the involved communities (Icom, 2020). The proposal is to give continuity to the community bank experience. To do this, partnerships have been formed with other local CSOs and communities and Icom is taking part of the community bank network in Brazil.

The second experience refers to the Street Network (Rede com a Rua), made up of 16 groups/ collectives/associations which develop actions together with homeless people in the city. This network already existed before the pandemic, and its members meet weekly with the street population to debate strategy to the cration of a center devoted to attend this this public. With the pandemic, and in light of the absence of a municipal emergency plan, these collectives have come to act in a joint manner, constituting a network, which is currently being formalized.

In articulation with the Secretariat of Social Assistance, the Street Network has conceived and implemented a strategy to distribute three meals a day on the Samba Nego Quirido overpass for roughly 300 people living on the street. The network also holds a registration campaign for users who don't come to the overpass to receive emergency aid, meals, and donations. Besides these actions, the Street Network has also played a central role in the construction of an agenda of proposals and mobilizations to advance public policies related to this subject. Among these proposals is the implementation of a popular restaurant in the city, the creation of new alternatives for low cost housing, and the review of procedures by how public servants and police approach homeless people - all detailed in a public pronouncement signed by the network on April 25 (Associação Rede Rua, 2020). 
Finally, we should look at the articulation promoted by the IVG Network together with the communities of Maçico do Morro da Cruz. IVG was created in 2011 as a way to increase the potential, actions and articulation of various organizations supported by Father Vilson Groh, a historic community leader of the city. Today, the IVG Network is made up of 6 SCOs, and also works in partnership with the Marist Group through the units of the São José Marist Educational Center and the Lucia Mayvorne Marist Educational Center (which functions in Monte Serrat and is free). The IVG Network has been active since the beginning of the pandemic, with the creation of an emergency support fund for the poor communities that it serves. Until June 2020, R \$278,539.11 had been mobilized and invested which resulted in 6,290 basic meals and hygiene and cleaning kits distributed to communities where the IVG network operates.

Their activities, however, are not limited to this. It can be highlighted the mobilization that resulted from an open letter supported by various other CSOs and city movements entitled Our Lives Matter. ${ }^{24}$ This letter contains demands of the communities and CSOs of Greater Florianopolis, such as: problems with access to the CRASs which are closed and functioning remotely; difficulties with the unified registration, emergency assistance and the receipt of occasional social assistance benefits; the vulnerabilities of immigrants; the increase in domestic violence and police violence in these communities.

Based on these demands, the letter ends with the following request: "Given these observations, it is therefore urgent that government managers present a PLAN TO FACE THIS PANDEMIC [...] To accomplish this, we suggest the CREATION OF A CRISIS TABLE bringing together representatives of the municipal health and social assistance secretariats and the CSOs to face the pandemic situation and also create LOCAL COMMITTEES to promote this intersectoral articulation and dialogue with community leaders" (Nossas vidas importam, p. 4).

These initiatives have in common the mobilization of various preexisting actors, networks, resources and learning related to the cocreation of experimentation communities which inquiry problems, debate, denounce and act, stimulating new responses for this crisis situation. This has led to the creation of new forms of coordination and the invention of new institutions and devices to face the undesirable consequences of the crisis. However, by looking at its interface with public actions, we can see that this experimentation faces everyday challenges that may limit its reach.

The first challenge observed refers to dialogue between emergent initiatives, the government and public policies. Since the beginning of social distancing in the city, as mentioned, the position of the City Hall has been to realize many social assistance operations through Somar Floripa, ${ }^{25}$ a network of volunteering promotion created by the municipal government and coordinated by the mayor's wife. Through the \#Somando campaign against COVID-19, which uses the city's Civil Defense Fund, the Somar Network has become the main protagonist, articulating the donations and the main channel of communication between the City Hall, the CSOs, the communities and the city's vulnerable populations. ${ }^{26}$ This has led to a lack of articulation of emergency actions promoted by the City Hall

\footnotetext{
${ }^{24}$ See https://www.redeivg.org.br/noticias/nossas-vidas-importam/

${ }^{25}$ For more information see http://somarfloripa.com/home/

${ }^{26}$ At the beginning of the pandemic in the city, the mayor's wife put a video on the social networks requesting donations arguing that "the campaigns need to come from reputable entities with transparent accounts" and that "the only two which do not charge an
} 
and the strategies and instruments of the Unified System of Social Assistance (SUAS), mainly CRAS, as well as the more active CSOs, since the actions of Somar are very controversial and questioned by the civil society field as well as the municipality's public servants. Irregularities in this prominent role for Somar, in an election year, have been investigated by the Ministry of Government Accounting and the Prosecutor's Office of Santa Catarina. ${ }^{27}$

As a result, this is related to another challenge: the lack of governmental initiatives, spaces and public policy instruments to promote articulation and dialogue with the actions promoted by organized civil society, hindering the construction of a common agenda and shared governance. This has led to the prevalence of an "owner of public problems" logic (Gusfield, 1982), making greater collaboration, intersectoral articulation and a broader dialogue between the government and emerging initiatives and between the initiatives themselves more difficult. The problems generated by this lack of governance have been felt, discussed and are manifested explicitly in the Our Lives Matter letter, as cited above, which has stimulated other more recent mobilizations in order to create intersectoral crisis governance committees in the city and within the region ${ }^{28}$.

Despite interventions are promoted for the same publics and the same problematic situations, the absence of collaborative governance could generate another challenge, leading to a dispersal of effort and a lack of review and control of this action. This could produce mimetic effects in these actions, discouraging innovation and generating overlaps and/or competition, or even rivalry, increasing the distrust. The communities, in turn, will end up benefitting more from isolated actions of social assistance than from a co-constructed public action. The asymmetry and distrust between the government and civil society, between the promoters and the beneficiaries, between experts and the communities could complicate the production of social innovations and their integration into public policies. These issues are more problematic given the dimensions of the crisis caused by the COVID-19 pandemic in the country, in the state of Santa Catarina and the city of Florianopolis, with a continual increase in the number of those infected and dying from this contagion, caused mainly by a lack of more effective governance and its effects.

administration fee and are officially authorized to do fundraising" are the bank accounts of the Emergency Municipal Civil Defense Fund of Florianopolis (Fundec) and the Social Venture (Empreenda Social) company, a city partner. The message generated a lot of controversy and resulted in a public note signed by various CSOs affirming the importance of the involvement of organized civil society in emergency and crisis situations.

${ }^{27}$ See the details at https://folhacidade.com.br/2020/04/16/mpsc-e-mp-de-contas-cobram-explicacoes-da-primeira-dama-deflorianopolis-sobre-doacoes-para-ajudar-atingidos-pelo-coronavirus/

${ }^{28}$ We should note here an official communication sent to the Public Policy Forum of the Municipal Government of Florianopolis in June as well as the public petition "Our Lives, Our Voices" signed by over 1,000 people and sent to mayors of the region, requesting the creation of intersectoral committees in municipalities and Greater Florianopolis for the governance of the crisis, which resulted in an articulation between the research groups of UDESC and UFSC, FPPF and the civil society organizations. To find out more see https:// www.facebook.com/forumdepoliticaspublicasdeflorianopolis. 


\section{CONCLUSION}

This devastating crisis caused by the pandemic requires that both the government as well as civil society reinvent themselves rapidly, within the context of an increase in demands and vulnerabilities, in which responses cannot be fixed a priori, decisions involve open processes, and the rules, in order to be respected, need to be co-constructed considering the plurality of situations, interests and actors involved. This requires to put in practice new forms of governance in which democratic experimentation can be inspiring. This means creating spaces for emerging social innovations so that they can dialogue between themselves and with the instituted powers, producing a renovation of the public institutions and actions, as has been discussed.

The evidences presented in this exploratory study on the national level as well as in the case of Florianopolis, make it possible to conclude that the performance of civil society in the fight against the COVID-19 pandemic have made a difference in terms of the resources mobilized and the actions promoted. However, when we observe this action more closely, we may perceive that it is has concentrated more on emergencies, producing scattered actions in the areas of social assistance and health support, above all for the most vulnerable populations and communities. On the other hand, other forms of collective actions have emerged in this scenario, generating social innovations and opening space for new practices of public governance.

For this experimentation to flourish, it appears necessary: (1) to reinforce the collaborative processes of resolution in the problematic situations caused by the pandemic, through societal-state interactions including various publics, mainly those affected, in the construction of solutions and in the appropriation of the generated learning and results; (2) an articulation between emerging powers and the inventiveness of civil society with the expertise, instruments and devices of public policies; (3) a continuous review, based on learning by trial and error, tests, transparency, coproduction and sharing of information and knowledge which produce collective intelligence to face this crisis.

In sum, it is central that the formal systems of governance in this crisis, above all within the local level, be open to see, learn and act together with the experimentations underway in the networks of civil society, many of which are still invisible. This signifies reinforcing a necessary process of democratization in public policies (Frega, 2019), which is not something that will occur once and for all, but will instead result in a continual engagement with the challenges and controversies of making everyday policy. Perhaps it is early to say that the interactions between civil society and the State have changed in a significant manner in this country with the COVID-19 pandemic, but without a doubt it may be perceived that they will no longer be the same after this crisis. Thus, understanding "whether" and "how" the new interfaces between civil society and the government will open spaces for possibilities to reinvent our democracy, given this new scenario, has become a central subject of the research agenda. 


\section{REFERENCES}

Abrucio, F. L., \& Teixeira, M. A. C. (2020). Formação para uma administração pública faz diferença. Folha de S. Paulo. Retrieved from https://wwwl.folha.uol. com.br/opiniao/2020/06/formacao-para-uma-boaadministracao-publica-faz-diferenca.shtml

Almeida, D. R. (2014). Pluralização da representação política e da legitimidade democrática: lições das IPs no Brasil. Opinião Pública, 20(1), 96-117.

Andion, C., Alperstedt, G. D., \& Graeff, J. F. (2020). Ecossistema de inovação social, sustentabilidade e experimentação democrática: um estudo em Florianópolis. Revista de Administração Pública, 54(1), 181-200.

Andion, C., Alperstedt, G. D., \& Graeff, J. F. (2019). Social Innovation Ecosystems and Cities: CoConstruction of a Collaborative Platform. In: J. Howaldt, C. Kaletka, A. Schröder, \& M. Zirngiebl (Eds.), Atlas of Social Innovation (2nd vol: A World of New Practices). Dortmund, Germany: TU Dortmund University, European School of Social Innovation.

Ansell, C. (2011). Pragmatist Democracy: Evolutionary Learning as Public Philosophy. Oxford, UK: Oxford Scholarship.

Associação Rede Rua. (2020). Posicionamento (mimeo). São Paulo, SP: Author.

Brandsen, T., Trommel, W., \& Verschuere, D. (2017). The state and the reconstruction of civil Society. International Review of Administrative Sciences, 83(4), 676-693.

Cefaï, D. (2007). Pourquoi se mobilise-t-on? Les théories de l'action collective. Paris, France: La Découverte/Mauss.

Cefaï D. (2012). Qu'est-ce qu'une arène publique? Quelques pistes pour une approche pragmatiste. In D. Cefaï, \& I. Joseph (Eds.), L'Héritage du pragmatisme: conflits d'urbanité et épreuves de civisme. La Tour d'Aigues, Vaucluse: Éditions de l'Aube.

Chateauraynaud, F. (2011). Los tópicos ambientales: entre controversias y conflictos. Revista Colombiana de Sociologia, 34(1), 13-40.

Cohen, J.-L., \& Arato, A. (1994). Civil Society and Political Theory. Cambridge, UK: MIT Press.
Cohen, J.-L., \& Sabel, C. F. (1997). Directlydeliberative Poliarchy. European Law Journal, 3, 313-340.

Dagnino, E. (2002). Sociedade civil e espaços públicos no Brasil. Rio de Janeiro, RJ: Paz e Terra.

Dewey, J. (1927). The Public and Its Problems. Chicago, USA: Swallow.

Frega, R. (2019). Pragmatism and the wide view of democracy. Gewerbestrasse, Switzerland: Palgrave Macmillan.

Gaudin, J.-P. (2002). Pourquoi la gouvernance. Paris, France: Presses de Sciences Po.

Gusfield, J. R. (1982). Contested Meanings: The Construction of Alchool Problems. Wisconsin, USA: University of Winsconsin Press.

Instituto Brasileiro de Geografia e Estatística. (2010). Asfundações privadas e associações sem fins lucrativos no Brasil (Estudos \& Pesquisas: informação econômica, 20). Rio de Janeiro, RJ: Author.

Landin, L, \& Scalon, M. C. (2000). Doações e trabalho voluntário no Brasil. Rio de Janeiro, RJ: 7Letras.

Lavalle, A. G., \& Szwako, J. (2015). Sociedade civil, Estado e autonomia: argumentos, contraargumentos e avanços no debate. Opinião Pública, 21(1), 157-187.

Levi-Faur, D. (2012). The Oxford Handbook of Governance. Oxford, UK: Oxford University Press.

Mccarthy, J., \& Zald, M. (1977). Ressource Mobilization and Social Movements: a Partial Theory. American Journal of Sociology, 82(6), 12121241.

Meyer, M., \& Maier, F. (2015). The future of civil Society organisation governance: beyond managerialism. In J.-L. Laville, D. R. Young, \& P. Eynaud (Eds.), Civil Society, the Third Sector na Social Enterprise. London, UK: Routledge.

Sabel, C. (2012). Dewey, Democracy and Democratic Experimentalism. Contenporary Pragmatism, 9(2), 35-55.

Sabel, C., \& Zeitlin, J. (2012). Experimentalist Governance. In D. Levi-Faur (Ed.), The Oxford Handbook of Governance. Oxford, UK: Oxford University Press. 
RAP | Civil society mobilization in coping with the effects of COVID-19 in Brazil

Salamon, L. M. (1995). Partners in Public Service: Government-Nonprofit Relations in the Modern Welfare State. London, UK: Johns Hopkins University Press.

Salamon, L. (2011). The New Governance and the Tools of Public Action: An Introduction. Fordham Urban Law Journal, 28(5), 1611-1674.
Tarrow, S. (2009). Opoderem movimento: movimentos sociais e confronto politico. Petrópolis, RJ: Vozes.

Young, D. R. (2000). Alternative models of government-nonprofit sector relations: Theoretical and international perspectives. Nonprofit and Voluntary Sector Quarterly, 29(1), 149-172.

\section{Carolina Andion}

https://orcid.org/0000-0003-4723-3437

Post-doctorate in Social Economics; Ph.D. in Interdisciplinary Human Sciences, and Associate Professor at the University of the State of Santa Catarina. E-mail: andion.esag@gmail.com 